\title{
Evaluation of Zinc in various Arums, Bananas, Vegetables and Pulses from Five Upazila of Chittagong region in Bangladesh by Spectro-photometric Method
}

\author{
Faridul Islam ${ }^{1,}$, Sreebash Chandra Bhattacharjee ${ }^{2}$, Abu Sayeed Mohammad \\ Mahmud $^{3}$, Md. Tofayal Hossain Sarkar ${ }^{4}$, Most. Afroza Khatun ${ }^{5}$, Mohammed \\ Abdus Satter ${ }^{6}$, Muhammad Shahjalal Khan ${ }^{7}$, Tarannum Taznin ${ }^{8}$ \\ ${ }^{1,2,3,4}$ Bangladesh Council of Scientific and Industrial Research (BCSIR) Laboratories, Chittagong. Chittagong- \\ 4220, Bangladesh \\ ${ }^{5}$ Chemical Engineering Department, Jessore Science \& Technology University, Bangladesh \\ ${ }^{6}$ Institute of Food Science and Technology, BCSIR, Dhaka, Bangladesh \\ ${ }^{7}$ Area Nutrition Officer, Nestle Bangladesh Limited \\ ${ }^{8}$ Department of Microbiology, Jessore Science and Technology University (JSTU), Bangladesh.
}

\begin{abstract}
Zinc is an essential element needed by the body in small amounts as it is the most abundant trace metals in human. It deficiency is occurring in different climate regions of the world. It has become an important risk factor for plant growth as well as human health throughout the world. In this study, we observed the amount of zinc in different arums, bananas, vegetables and pulses which are locally available in Chittagong region of Bangladesh. The amount of zinc in twenty samples of arums was found to vary from 0.3174-9.0755 $\mu \mathrm{g} / \mathrm{g}$. The highest and lowest value was found in arums of Typhonium trilobatum (Patiya) and Amorphophallus campanulatus (Satkaniya) respectively. In bananas vary from 0.1430 to $2.7360 \mu \mathrm{g} / \mathrm{g}$. The highest and lowest value was found in banana of Musa acuminata in Satkania and Ramgarh upazila respectively. The amount of zinc in vegetables was found to vary from 0.92-7.59 $\mu \mathrm{g} / \mathrm{g}$. Zinc in pulses were found to vary from 1.2973$29.5008 \mu \mathrm{g} / \mathrm{g}$. The highest and lowest values were found in Lathyrus sativus and Phaseolus aureus respectively. From four types of food, we see that the highest value of zinc in pulse species of Lathyrus sativus and the lowest value of zinc in banana species of Musa acuminata respectively of Chittagong region, Bangladesh.

Key words: Zinc, Arum, Banana, Vegetable and Pulse.
\end{abstract}

\section{Introduction}

Zinc element commonly found in the Earth's crust. Because of its reactivity, zinc metal is not found as the free element in nature. There are approximately 55 mineralized forms of zinc. The most important zinc minerals in the world are sphalerite $(\mathrm{ZnS})$, smithsonite $\left(\mathrm{ZnCO}_{3}\right)$, and hemimorphite $\left(\mathrm{Zn}_{4} \mathrm{Si}_{2} \mathrm{O}_{7}(\mathrm{OH}) 2 \mathrm{H}_{2} \mathrm{O}\right)$. $\mathrm{Zinc}$ appears in Group IIB of the periodic table and has two common oxidation states, $\mathrm{Zn}(0)$ and $\mathrm{Zn}(+2)$. $\mathrm{Zinc}$ forms a variety of different compounds such as zinc chloride, zinc oxide, and zinc sulfate [1]. Zinc occurs in the environment mainly in the +2 oxidation state [2].

Zinc is an essential nutrient in humans and animals that is necessary for the function of a large number of metallo-enzymes. These enzymes include alcohol dehydrogenase, alkaline phosphatase, carbonic anhydrase, leucine aminopeptidase, superoxide dismutase, and deoxyribonucleic acid (DNA) and ribonucleic acid (RNA) polymerase. As such, zinc is required for normal nucleic acid, protein, and membrane metabolism, as well as cell growth and division. Zinc is also play an essential role in the maintenance of nucleic acid structure of genes (zinc finger phenomenon). Zinc deficiency has been associated with dermatitis, anorexia, growth retardation, poor wound healing, hypogonadism with impaired reproductive capacity, impaired immune function, and depressed mental function; increased incidence of congenital malformations in infants has also been associated with zinc deficiency in the mothers [3, 4]. Zinc deficiency may also have an impact on carcinogenesis, though the direction of the influence seems to vary with the agent $[5,6,7]$. Therefore, certain levels of zinc intake are recommended. The daily needs or the world's daily average uptake of $15 \mathrm{mg} / \mathrm{day}$ zinc is considered to be suitable for human adults by weighing of $70 \mathrm{~kg}$ [8]. It is necessary for proper growth and development of young children. Mothers who did not eat enough zinc during pregnancy had a higher frequency of birth defects and gave birth to smaller children (lower birth weight) than mothers whose zinc levels were sufficient. Very young children who did not receive enough zinc in the diet were smaller, both in length and in body weight, than children who ate enough zinc.

It enters the air, water, and soil as a result of both natural processes and human activities. Most zinc enters the environment as the result of mining, purifying of zinc, lead, and cadmium ores, steel production, coal burning, and burning of wastes. These activities can increase zinc levels in the atmosphere. Waste streams from 
zinc and other metal manufacturing and zinc chemical industries, domestic waste water and run-off from soil containing zinc can discharge zinc into water ways. The level of zinc in soil increases mainly from disposal of zinc wastes from metal manufacturing industries and coal ash from electric utilities. Sludge and fertilizer also contribute to increased levels of zinc in the soil. [9] found concentrations of zinc were highest in grass samples.

Zinc compounds have dental, medical, and household applications. In pharmaceuticals, zinc salts are used as solublizing agents in many drugs, including insulin $[10,11]$. Zinc compounds are utilized therapeutically in human medicine in the treatment of zinc deficiency [12].

Chittagong is the commercial capital city of Bangladesh. Many types of Industry were built in this city. For that reason, we try to find out the amount of zinc from various substances. The climate of Bangladesh is proper for growing of various arums, bananas, vegetables and pulses. The people can easily collect arums, bananas, vegetables and pulses from local market by cheap rate or they can grow easy way to this arums, bananas, vegetables and pulses. Various arums, bananas, vegetables and pulses are contains various amount of zinc. In the present investigation, the amount of zinc in some arums, bananas, vegetables and pulses are determined by spectro-photometric method.

\section{Methods}

Twenty samples of each item i.e. arums, bananas, vegetables and pulses were collected from various upazila of Chittagong region, Bangladesh. All samples were washed with water followed with DDI (double deionized distil water). Samples were cut into small pieces and dried at $105^{\circ} \mathrm{C}$ for $18 \mathrm{hrs}$ [13]. After drying, the samples were burned into the maffle furnace and then the ashes were weighed and stored in the stopper bottle. Taking the weight of the ash sample, the amount of $\mathrm{Zn}$ present in the sample was determined by using conventional methods [14].

\section{Results}

The investigation on the collected sample of various Arums, Bananas, Vegetables and Pulses are presented by the value. The sample data in various Arums, Bananas, Vegetable and Pulses are presented in Table-1,5,7 and11 respectively and the reference table is $2,3,4,6,8,9,10,12$ and 13 respectively. The amount of zinc in pulse is greater than Arums, Bananas and Vegetables. Specially, pulse species of Lathyrus sativus (Anowara) contain the highest value of zinc and the amount is $29.5008 \mu \mathrm{g} / \mathrm{g}$. On the other hand, banana species of Musa acuminata (Ramgarh) contain lowest value of zinc and the amount is $0.1430 \mu \mathrm{g} / \mathrm{g}$.

\section{Discussions}

Food is the major source of zinc for the general population (EPA 1987c). Taking too much zinc into the body through food, water or dietary supplements can also affect health. The levels of zinc that produce adverse health effects are much higher than the Recommended Dietary Allowances (RDAs). If large doses of zinc (1015 times higher than the RDA) are taken by mouth even for a short time, stomach cramps, nausea and vomiting may occur. Ingesting high levels of zinc for several months may cause anemia, damage the pancreas, and decrease levels of high-density lipoprotein (HDL) cholesterol. Just as zinc deficiency has been associated with adverse effects in humans and animals, overexposures to zinc also have been associated with toxic effects. In humans, death has resulted from acute exposure to zinc compounds. When a high concentration (estimated at $33,000 \mathrm{mg} \mathrm{zinc} / \mathrm{m} 3$ ) of zinc chloride smoke resulted from the explosion of many generators in a tunnel following a bombing raid in World War II, 10 of the 70 exposed people in the tunnel died within 4 days [15].

The selected region of the Chittagong in Bangladesh, the value of zinc in various Arums of various upazila of Chittagong is differ from Tanzania and Uganda and different countries of world as shown in table- 1, 2 and 3. The highest value of arum species of Typhonium trilobatum is $9.0755 \mu \mathrm{g} / \mathrm{g}$ and the second highest arum species of Colocasia esculenta is $4.5988 \mu \mathrm{g} / \mathrm{g}$. The mineral element list of any adult person as shown in table- 4 .

In Nigeria, the value of zinc in Banana is very much greater than Bangladesh as shown in table- 5 and 6 . Approximately, all substances contain lowest amount of zinc.

The value of various vegetables in Pakistan and India is greater than Bangladesh as shown in table- 7, 8, 9 and 10. Only Ipomoea aquatica contains the higher value than other species of vegetables and the value is $7.59 \mu \mathrm{g} / \mathrm{g}$.

The various pulses are the same as India and Pakistan is greater than Bangladesh as shown in table-11,

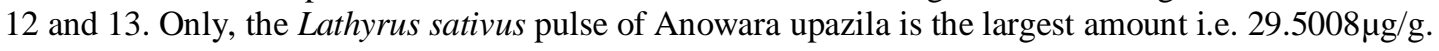


Table 1: Amount of $\mathrm{Zn}^{2+}(\mu \mathrm{g} / \mathrm{g})$ in various arums in various upazila of Chittagong region, Bangladesh.

\begin{tabular}{|c|c|c|c|c|}
\hline $\begin{array}{l}\text { Bengali name of } \\
\text { arums }\end{array}$ & $\begin{array}{l}\text { English name of } \\
\text { arums }\end{array}$ & $\begin{array}{l}\text { Biological name of } \\
\text { arums }\end{array}$ & $\begin{array}{l}\text { Name of the } \\
\text { Upazilas }\end{array}$ & $\begin{array}{l}\text { Amount of } \\
\mathrm{Zn2}(\mu \mathrm{g} / \mathrm{g}) \text { in } \\
\text { arums }\end{array}$ \\
\hline \multirow[t]{5}{*}{ Pani Kachu } & \multirow[t]{5}{*}{ Eddoe } & \multirow[t]{5}{*}{ Colocasia esculenta } & Patiya & 4.5988 \\
\hline & & & Chandanish & 0.4773 \\
\hline & & & Satkaniya & 3.0799 \\
\hline & & & Lohagara & 0.4663 \\
\hline & & & Boalkhali & 0.5959 \\
\hline \multirow[t]{5}{*}{ Mukhi Kachu } & \multirow[t]{5}{*}{ Taro } & \multirow[t]{5}{*}{ Typhonium trilobatum } & Patiya & 9.0755 \\
\hline & & & Chandanish & 3.1424 \\
\hline & & & Satkaniya & 0.8783 \\
\hline & & & Lohagara & 0.5869 \\
\hline & & & Boalkhali & 0.9832 \\
\hline \multirow[t]{5}{*}{ Man kachu } & \multirow[t]{5}{*}{ Giant taro } & \multirow[t]{5}{*}{ Alocasia indica } & Patiya & 2.6394 \\
\hline & & & Chandanish & 0.621 \\
\hline & & & Satkaniya & 2.0713 \\
\hline & & & Lohagara & 3.2671 \\
\hline & & & Boalkhali & 3.2566 \\
\hline \multirow[t]{5}{*}{ Oal Kachu } & \multirow{5}{*}{$\begin{array}{l}\text { Elephant foot } \\
\text { yam }\end{array}$} & \multirow{5}{*}{$\begin{array}{l}\text { Amorphophallus } \\
\text { campanulatus }\end{array}$} & Patiya & 4.4961 \\
\hline & & & Chandanish & 4.4314 \\
\hline & & & Satkaniya & 0.3174 \\
\hline & & & Lohagara & 4.2048 \\
\hline & & & Boalkhali & 1.7196 \\
\hline
\end{tabular}

Table 2: Amount of $\mathrm{Zn}^{2+}(\mathrm{mg} / \mathbf{1 0 0 g})$ in various Arums determined from Tanzania and Uganda [16]

\begin{tabular}{|l|l|l|}
\hline Biological name of Arums & Amount of $\mathrm{Zn}^{2+}(\mathrm{mg} / 100 \mathrm{~g})$ in Arums \\
\cline { 2 - 3 } & Tanzania & Uganda \\
\hline Colocasia esculenta & $5.63 \pm 0.04$ & $3.01 \pm 0.34$ \\
\hline Xanthosoma sagittifolium & $1.35 \pm 0.13$ & $4.08 \pm 0.55$ \\
\hline
\end{tabular}

Table 3: Amount of $\mathrm{Zn}(\mathrm{mg} / \mathbf{1 0 0 g})$ in various varieties of edible aroids from different countries [17]

\begin{tabular}{|c|l|}
\hline Biological name of Edible aroids & Amount of $\mathrm{Zn}^{2+}(\mathrm{mg} / 100 \mathrm{~g})$ in Edible aroids \\
\hline Colocasia esculenta & 3.8 \\
\hline Xanthosoma spp & 0.52 \\
\hline Alocasia spp & 1.57 \\
\hline Cyrtosperma chamissonis & 2.3 \\
\hline Amorphophallus campanulatus & 1.05 \\
\hline
\end{tabular}

Table 4: The daily needs or the worlds daily average up-take of elements by a person weighing $70 \mathrm{~kg}$ [8]

\begin{tabular}{|l|l|}
\hline Element & Average Daily Dietary Intake (mg/day) Range \\
\hline $\mathrm{Fe}$ & $15(10-28)$ \\
\hline $\mathrm{Mn}$ & $2.8(2-5)$ \\
\hline $\mathrm{Zn}$ & 15 \\
\hline $\mathrm{Cu}$ & $2.5(2-3)$ \\
\hline $\mathrm{Ni}$ & 0.025 \\
\hline $\mathrm{Cr}$ & $0.05-0.02$ \\
\hline $\mathrm{Co}$ & 0.04 \\
\hline $\mathrm{Pb}$ & 0.415 \\
\hline $\mathrm{Cd}$ & 0.057 \\
\hline
\end{tabular}


Table 5: Amount of $\mathrm{Zn}^{2+}(\mu \mathrm{g} / \mathrm{g})$ in various bananas in various upazila of Chittagong region, Bangladesh.

\begin{tabular}{|c|c|c|c|c|}
\hline $\begin{array}{l}\text { Bengali name of } \\
\text { bananas }\end{array}$ & $\begin{array}{l}\text { English name of } \\
\text { bananas }\end{array}$ & $\begin{array}{l}\text { Biological name of } \\
\text { bananas }\end{array}$ & $\begin{array}{l}\text { Name of the } \\
\text { Upazilas }\end{array}$ & $\begin{array}{l}\text { Amount of } \mathrm{Zn}^{2+} \\
(\mu \mathrm{g} / \mathrm{g}) \text { in bananas }\end{array}$ \\
\hline \multirow{5}{*}{ Bangla kala } & \multirow{5}{*}{ Lady finger banana } & \multirow{5}{*}{ Musa sapietum } & Hathazari & 0.9610 \\
\hline & & & Anowara & 0.3010 \\
\hline & & & Satkania & 0.3490 \\
\hline & & & Lama & 2.05 \\
\hline & & & Ramgarh & 1.187 \\
\hline \multirow[t]{5}{*}{ Champa kala } & \multirow[t]{5}{*}{ Champa banana } & \multirow[t]{5}{*}{ Musa acuminata } & Hathazari & 0.678 \\
\hline & & & Anowara & 1.934 \\
\hline & & & Satkania & 2.736 \\
\hline & & & Lama & 1.552 \\
\hline & & & Ramgarh & 0.1430 \\
\hline \multirow[t]{5}{*}{ Sagor kala } & \multirow[t]{5}{*}{ Cavendish banana } & \multirow[t]{5}{*}{ Musa cavendishii } & Hathazari & 0.6070 \\
\hline & & & Anowara & 1.0980 \\
\hline & & & Satkania & 1.5950 \\
\hline & & & Lama & 0.5860 \\
\hline & & & Ramgarh & 0.5750 \\
\hline \multirow[t]{5}{*}{ Kanch kala } & \multirow[t]{5}{*}{ Green banana } & \multirow[t]{5}{*}{ Musa paradisiaca } & Hathazari & 0.6450 \\
\hline & & & Anowara & 0.2980 \\
\hline & & & Satkania & 0.4040 \\
\hline & & & Lama & 1.5050 \\
\hline & & & Ramgarh & 0.3570 \\
\hline
\end{tabular}

Table 6: Amount of $\mathrm{Zn}^{2+}(\mathrm{mg} / \mathrm{Kg})$ in various bananas of Nigeria [18]

\begin{tabular}{|c|c|}
\hline Nigerian name of bananas & Amount of $\mathbf{Z n}^{\mathbf{2 +}}(\mathbf{m g} / \mathbf{K g})$ in bananas \\
\hline Musa Gross Michel (lgbo banana) & 2.90 \\
\hline Musa Sapientum(paranta) & 20.90 \\
\hline Musa paradisiacal(plantain) & 31.10 \\
\hline Musa 'Wild banana'(Omini) & 10.10 \\
\hline Musa 'Red'(Sweet banana) & 21.10 \\
\hline Musa 'Fugamo'(Somupeke) & 12.10 \\
\hline
\end{tabular}

Table 7: Amount of $\mathrm{Zn}^{2+}(\mu \mathrm{g} / \mathrm{g})$ in various vegetables in various upazila of Chittagong region, Bangladesh.

\begin{tabular}{|c|c|c|c|c|}
\hline $\begin{array}{l}\text { Bengali } \\
\text { name of } \\
\text { vegetables }\end{array}$ & $\begin{array}{l}\text { English name of } \\
\text { vegetables }\end{array}$ & $\begin{array}{l}\text { Biological name of } \\
\text { vegetables }\end{array}$ & $\begin{array}{l}\text { Name of the } \\
\text { Upazilas }\end{array}$ & $\begin{array}{l}\text { Amount of } \\
\mathrm{Zn}^{2+}(\mu \mathrm{g} / \mathrm{g}) \\
\text { in } \\
\text { vegetables }\end{array}$ \\
\hline \multirow{5}{*}{$\begin{array}{l}\text { Helencha } \\
\text { Shak }\end{array}$} & \multirow[t]{5}{*}{ Water cress } & \multirow[t]{5}{*}{ Enhydra fluctuans } & Hathazari & 7.19 \\
\hline & & & Patia & 3.34 \\
\hline & & & Anowara & 1.98 \\
\hline & & & Pahartali & 6.59 \\
\hline & & & Fatickchari & 0.92 \\
\hline \multirow{5}{*}{$\begin{array}{l}\text { Moloncha } \\
\text { Shak }\end{array}$} & \multirow[t]{5}{*}{ Alligator weed } & \multirow{5}{*}{$\begin{array}{l}\text { Alternanthera } \\
\text { philoxeroides }\end{array}$} & Hathazari & 1.45 \\
\hline & & & Patia & 1.37 \\
\hline & & & Anowara & 1.47 \\
\hline & & & Pahartali & 6.53 \\
\hline & & & Fatickchari & 1.24 \\
\hline \multirow[t]{5}{*}{ Kolmi Shak } & \multirow[t]{5}{*}{ Swamp cabbage } & \multirow[t]{5}{*}{ Ipomoea aquatica } & Hathazari & 7.59 \\
\hline & & & Patia & 2.31 \\
\hline & & & Anowara & 1.62 \\
\hline & & & Pahartali & 1.79 \\
\hline & & & Fatickchari & 3.69 \\
\hline \multirow{5}{*}{$\begin{array}{l}\text { Thankuni } \\
\text { Pata }\end{array}$} & \multirow[t]{5}{*}{ Indian pennywort } & \multirow[t]{5}{*}{ Centella asiatica } & Hathazari & 2.07 \\
\hline & & & Patia & 1.34 \\
\hline & & & Anowara & 5.12 \\
\hline & & & Pahartali & 3.73 \\
\hline & & & Fatickchari & 3.12 \\
\hline
\end{tabular}


Table 8: Amount of $\mathrm{Zn}^{2+}(\mu \mathrm{g} / \mathrm{g})$ in various vegetables of Pakistan [19, 20]

\begin{tabular}{|l|l|}
\hline Biological name of vegetables & Amount $\mathbf{~ o f ~} \mathbf{Z n}^{2+}(\boldsymbol{\mu g} \mathbf{g})$ in vegetables \\
\hline Mentha sapicata & 43 \\
\hline Brassica rapa & $32.64 \pm 6.381$ \\
\hline Luffa acutangula & 59 \\
\hline Murraya koenigii & $12.77 \pm 0.994$ \\
\hline Brassica oleracea & $11.54 \pm 0.397$ \\
\hline
\end{tabular}

Table 9: Amount of $\mathrm{Zn}^{2+}(\mu \mathrm{g} / \mathrm{g})$ in various vegetables of India $[19,21]$

\begin{tabular}{|l|l|}
\hline Biological name of vegetables & Amount of $\mathbf{Z n}^{2+}(\boldsymbol{\mu g} \mathbf{g} \mathbf{g})$ in vegetables \\
\hline Mentha sapicata & $41.4-47.4$ \\
\hline Brassica rapa & $28.8-30.3$ \\
\hline Luffa acutangula & 5.79 \\
\hline Ipomoea hederacea & 45 \\
\hline
\end{tabular}

Table 10: Amount of $\mathrm{Zn}^{2+}(\mathrm{ig} / \mathrm{Kg})$ in various Leafy vegetables in Assam of India [22]

\begin{tabular}{|l|l|}
\hline Biological name of vegetables & $\mathbf{A m o u n t}_{\left.\mathbf{~ o f ~} \mathbf{~ Z n}^{2+} \mathbf{( i g} / \mathbf{K g}\right) \text { in vegetables }}$ \\
\hline Brassica capitala & $46.45( \pm 7.15)$ \\
\hline Colocasia esculanta & $32.27( \pm 10.86)$ \\
\hline Brassica esculanta & $72.23( \pm 1.24)$ \\
\hline Brassica oleraceae & $33.79( \pm 1.06)$ \\
\hline Spinacea oleracea & $54.15( \pm 0.19)$ \\
\hline Coriendrum sativum & $34.41( \pm 7.60)$ \\
\hline Cucurbita maxima & $66.74( \pm 10.50)$ \\
\hline Amaranthus viridis & $27.66( \pm 7.49)$ \\
\hline
\end{tabular}

Table 11: Amount of $\mathrm{Zn}^{2+}(\mu \mathrm{g} / \mathrm{g})$ in various pulses in various upazila of Chittagong region, Bangladesh.

\begin{tabular}{|c|c|c|c|c|}
\hline $\begin{array}{l}\text { Bengali name of } \\
\text { pulses }\end{array}$ & $\begin{array}{l}\text { English name of } \\
\text { pulses }\end{array}$ & $\begin{array}{l}\text { Biological name of } \\
\text { pulses }\end{array}$ & $\begin{array}{l}\text { Name of the } \\
\text { Upazilas }\end{array}$ & $\begin{array}{l}\text { Amount of } \\
(\mu \mathrm{g} / \mathrm{g}) \text { in pulses }\end{array} \mathbf{Z n}^{2+}$ \\
\hline \multirow[t]{5}{*}{ Mash kalai } & \multirow[t]{5}{*}{ Black gram } & \multirow[t]{5}{*}{ Vigna muиngo } & Hathazari & 1.9782 \\
\hline & & & Anowara & 16.4310 \\
\hline & & & Rawzan & 5.7112 \\
\hline & & & Mirsharai & 1.8604 \\
\hline & & & Chandanaish & 3.4766 \\
\hline \multirow[t]{5}{*}{ Felon kalai } & \multirow[t]{5}{*}{ Southern pea } & \multirow[t]{5}{*}{ Phaseolus vulgaris } & Hathazari & 4.9263 \\
\hline & & & Anowara & 4.7369 \\
\hline & & & Rawzan & 1.9232 \\
\hline & & & Mirsharai & 1.3559 \\
\hline & & & Chandanaish & 5.9140 \\
\hline \multirow[t]{5}{*}{ Mung kalai } & \multirow[t]{5}{*}{ Green gram } & \multirow[t]{5}{*}{ Phaseolus aureus } & Hathazari & 1.2973 \\
\hline & & & Anowara & 5.1217 \\
\hline & & & Rawzan & 3.9165 \\
\hline & & & Mirsharai & 3.2554 \\
\hline & & & Chandanaish & 5.0324 \\
\hline \multirow[t]{5}{*}{ Kheshari kalai } & \multirow[t]{5}{*}{ Grass pea } & \multirow[t]{5}{*}{ Lathyrus sativus } & Hathazari & 4.8318 \\
\hline & & & Anowara & 29.5008 \\
\hline & & & Rawzan & 5.4740 \\
\hline & & & Mirsharai & 2.1903 \\
\hline & & & Chandanaish & 8.3378 \\
\hline
\end{tabular}

Table 12: Amount of $\mathrm{Zn}^{2+}(\mathrm{ig} / \mathrm{Kg})$ in various Pulses of India [22]

\begin{tabular}{|l|l|}
\hline Biological name of Pulses & Amount of $\mathbf{Z n}^{\mathbf{2 +}}(\mathbf{i g} / \mathbf{K g})$ in Pulses \\
\hline Lens culinaris & $58.05( \pm 13.37)$ \\
\hline Phaseolus mungo & $58.32( \pm 8.68)$ \\
\hline Cayaners cajan & $50.63( \pm 8.74)$ \\
\hline
\end{tabular}

Table 13: Amount of $\mathrm{Zn}^{2+}(\mathrm{mg} / 100 \mathrm{~g})$ in various Pulses of Pakistan (Hamid U. S. et al. 2011; M. Z. Haq et al.)

\begin{tabular}{|l|l|}
\hline Biological name of Pulses & Amount of $\mathbf{Z n}^{2+}(\mathbf{m g} / \mathbf{1 0 0 g})$ in Pulses \\
\hline Phaseolus aureus & 3.25 \\
\hline Lens culinaris & $4.2-4.4$ \\
\hline
\end{tabular}




\section{Conclusion}

Bangladesh is a densely populated and an agricultural country. Currently, the population is 16 crore and the area is 1,47,570 square kilometer. Most of the peoples of our country are poor and they live in village. So, they cannot buy zinc sufficient food. Zinc deficiency has been associated with dermatitis, anorexia, growth retardation, poor wound healing, hypogonadism with impaired reproductive capacity, impaired immune function and depressed mental function etc. It may also have an impact on carcinogenesis. The persons, who suffer from zinc deficiency, can get relieve of their diseases by selecting the zinc rich arums, bananas, vegetables and pulses. The study shows the amount of zinc is very higher in Lathyrus sativus pulse of Anowara Upazila and lower in Musa acuminata banana of Ramgarh Upazila. The reason for this trend is because of high translocation and transpiration rate of pulses in which transfer of metals from root to stem and ultimately to fruit. If they are unable to buy arums, bananas, vegetables and pulses from the market then they can grow such arums, bananas, vegetables and pulses in their garden or field. This analysis provides a base line data for our efforts directed towards maintaining a healthy life style.

\section{Acknowledgment}

The research was supported by Bangladesh Council of Scientific and Industrial Research (BCSIR).

\section{References}

[1] Goodwin FE. 1998. Zinc compounds. In: Kroschwitz J, Howe-Grant M, eds. Kirk-Othmer encyclopedia of chemical technology. New York, NY: John Wiley \& Sons, Inc.840-853.

[2] Lindsay WL. 1979. Chemical equilibria in soils. New York, NY: John Wiley \& Sons, 210-220.

[3] Cotran RS, Kumar V, Robbins SL.1989. Robbins pathologic basis of disease. 4th ed. Philadelphia, PA: W.B. Saunders Company, (pp. 461).

[4] Elinder CG.1986. Zinc. In: Friberg L, Nordberg FF, Vouk V, eds. Handbook on the toxicology of metals. Vol. II. (664-679.)New York, NY: Elsevier Science Publishers B.V

[5] Fong LYY, Sivak A, Newberne PM 1978. Zinc deficiency and methylbenzylnitrosoamine-induced esophageal cancer in rats. J Natl Cancer Inst 61:145-150.

[6] Mathur A, Wallenius K, Abdulla M. 1979. Influence of zinc on onset and progression of oral carcinogenesis in rats. Acta Odontologica Scand 37:377-384.

[7] Wallenius K, Mathur A, Abdulla M.1979. Effect of different levels of dietary zinc on development of chemically induced oral cancer in rats. Int J Oral Surg 8:56-62.

[8] Mahan, LK and Scott-Stump, S 1996. Krause's food Nutrition and Diet Therapy. Saunders company, Philadelphia, Pennsylvania.

[9] Bache CA, Gutenmann WH, Rutske M, et al. 1991. Concentrations of metals in grasses in the vicinity of a municipal refuse incinerator. Arch Environ Contam Toxicol 20:538-542.

[10] Lloyd TB, Showak W.1984. Zinc and zinc alloys. In: Grayson M, ed. Kirk-Othmer encyclopedia of chemical technology. 3rd Edition, vol. 24. New York, NY: John Wiley and Sons 835-836.

[11] Windholz M. 1983. Merck index. 10th ed. Rahway, NJ: Merck \& Co., Inc., 14551458.

[12] Keen CL, Hurley LS. 1977. Zinc absorption through skin: Correction of zinc deficiency in the rat. Am J Clin Nutr 30:528-530.

[13] Wiermans D, and Ven Ghoor B G, 1986. Cadmium, Lead, Mercury and Arsenic concentration in crops and corresponding soil in Netherlands. J Agric. Food Chem. 34: 1067.

[14] Vogel's 1978. Text book of quantitative inorganic analysis, 4th edition [15] Evans EH. 1945. Casualties following exposure to zinc chloride smoke. Lancet 249:368-370

[16] Ndabikunze B. K. 1*, Talwana H. A. L. 2, Mongi R. J. 1, Issa-Zacharia A.1, Serem A. K.3, Palapala V.4 and Nandi J. O. M.5 Proximate and mineral composition of cocoyam (Colocasia esculenta L. and Xanthosoma sagittifolium L.) grown along the Lake Victoria Ohnesorge FK, Wilhelm M. 1991. Zinc. Metals and their compounds in the environment. Weihieim, NY: VCH, 1309-1333.

[17] Linus U. Opara, Organisation: Massey University, Private Bag 11-222, Palmerston North, New Zealand Massey University, EDIBLE AROIDS: Post-Harvest Operation

[18] Joshua O. Babayemi, Khadijah T. Dauda, Abideen A.A.Kayode, Davies O. Nwude, John A Ajiboye, Enobong R. Essien and Olufunmilayo O. Abiona, Determination of potash alkali and metal contents of ashes obtained from peels of some varieties of Nigeria grown Musa Species. Bioresources.com

[19] Sumayya Saied, Erum Zahir and Azhar Siddique 2010. Heavy metals level in commonly used Traditional medicinal plants. J.Chem.Soc.Pak., Vol.32, No.6,

[20] Javid Hussain1*, Najeeb Ur Rehman1, Abdul Latif Khan1, 2, Muhammad Hamayun3, S. Murtaza Hussain1 Zabta Khan Shinwari4* 2010.Proximate And Essential Nutrients Evaluation Of Selected Vegetables Species From Kohat Region, 42(4): 2847-2855.

[21] Monu Arora a ,*, Bala Kiran ${ }^{\text {b }}$, Shweta Rani ${ }^{\text {a }}$, Anchal Rani a , Barinder Kaur ${ }^{\text {a }}$, Neeraj Mittal a 2008 . Heavy metal accumulation in vegetables irrigated with water from different sources. www.elsevier.com/locate/foodchem, 111: 811-815.

[22] Anjali Haloi1, Clarice R. Thabah2, D.K. Limbu1, Paul S. Dkhar2 and Rahul Chakraborty2 2010. Assessment of Certain Essential Elements in Some Common Edibles from Dadara and Agyathuri Villages of Kamrup District of Assam. J Hum Ecol $31(2)$ : $79-85$.

[23] Hamid Ullah Shah*, Umbreen Latif Khan*, Sahib Alam*, Anwar Ali Shad*, Zafar Iqbal* And Sajida Parveen** 2011. Effect Of Home Cooking On The Retention Of Various Nutrients In Commonly Consumed Pulses In Pakistan, Sarhad J. Agric Vol.27, No.2

[24] M. Zia-Ul-Haq1, S. Ahmad2*, M. Aslam Shad3, S. Iqbal4, M. Qayum5, A. Ahmad6, D. L. Luthria7 And R. Amarowicz8, Compositional Studies Of Lentil 